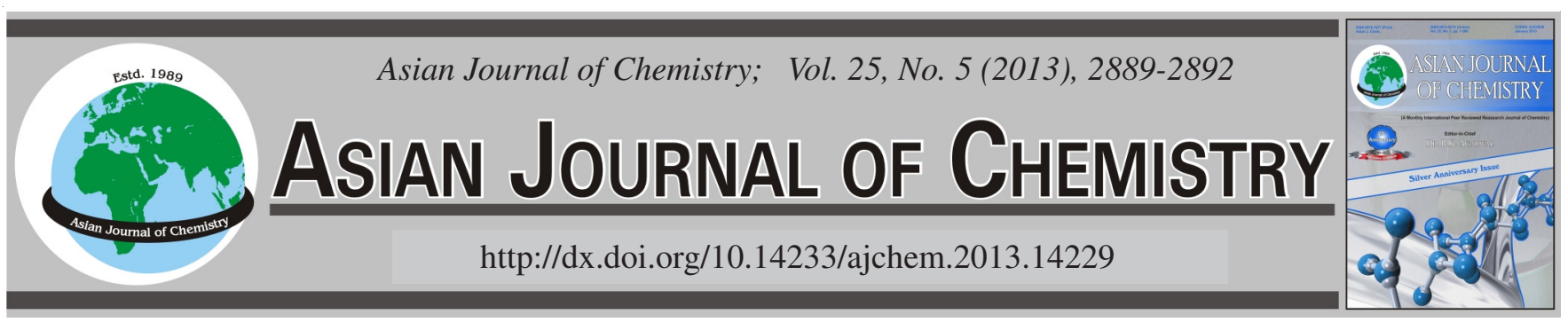

\title{
Antibacterial Properties of Clay Layers Silicate: A Special Study of Montmorillonite on Cotton Fiber
}

\author{
Ali Sadeghian Maryan ${ }^{1, *}$, Majid Montazer ${ }^{2}$, Abousaied Rashidi $^{1}$, Mohammad Karim Rahimi $^{3}$
}

\begin{abstract}
${ }^{1}$ Department of Textile Engineering, Science and Research Branch, Islamic Azad University, Tehran, Iran
${ }^{2}$ Department of Textile Engineering, Amirkabir University of Technology, Tehran, Iran

${ }^{3}$ Tehran Medical Branch, Islamic Azad University, Tehran, Iran

*Corresponding author: Email: texasm.phd@gmail.com
\end{abstract}

\begin{abstract}
Many antibacterial compounds, with different natural and synthetic structures, have been developed during past decades. This paper reports the antibacterial properties of silicate clay (montmorillonite) and cotton treated with montmorillonite clay. Different concentration of montmorillonite clay and modified montmorillonite clay with quaternary ammonium salt (A-MMT) were applied to cotton fabric. The antibacterial activity of clay and treated cotton with clay were evaluated according to AATCC 100. Antibacterial effects of montmorillonite clay with quaternary ammonium salt and montmorillonite clay were satisfactory against two types of bacteria: Staphylococcus aureus and Escherichia coli. Also, the same results on the loaded cotton with montmorillonite clay with quaternary ammonium salt and montmorillonite clay were obtained.
\end{abstract}

Key Words: Clay layers silicate, Antibacterial agent, Cotton, Montmorillonite, Modified montmorilonite.

\section{INTRODUCTION}

Many heavy metallic compounds have an effect on bacteria; the inner protein molecules of bacteria react with metal particles and as a result the bacteria will be killed. Metals such as copper, zinc, cobalt and silver are used as antimicrobial agents ${ }^{1-}$ ${ }^{4}$. Bacteria are one-cell organisms which grow rapidly under thermal and humid conditions. Hence, the cotton as cellulosic fiber is a very proper place for bacteria's growth. Antimicrobial agents are widely used in textile industry to control the growth of bacteria, fungi, molds and algae . $^{5-7}$.

Quaternary ammonium compounds are widely used as antibacterial agents. They have positive charges in the $\mathrm{N}$ atom in the solution and cause damage to the cellular membrane, denaturation of proteins and decomposition of cellular structure. Most of the bacterial surfaces have negative charge and absorbed by the cation of cation compounds breaking the cytoplasmic membrane and penetrating into microbial cell leading to the death of the bacteria cell ${ }^{8-11}$. The sulphonamides were used as drug since 1935 and have antioxoplasmic and anticancer properties ${ }^{12}$.

Layer silicates clay such as magadiite, mica, saponite, fluorohectorite and montmorillonite are natural earthy, finegrained material largely composed of crystalline substances that make up the group of clay minerals. The clay minerals are hydrated aluminum silicates usually containing alkaline, alkaline earth and iron appreciable quantities. Montmorillonite and mica have the best structure and properties for being utilized in textile industry. Montmorillonite with the chemical structure of $(\mathrm{Na}, \mathrm{Ca})_{0.33}(\mathrm{Al}, \mathrm{Mg})_{2}\left(\mathrm{Si}_{4} \mathrm{O}_{10}\right)(\mathrm{OH})_{2 \mathrm{n}} \cdot \mathrm{H}_{2} \mathrm{O}$, are composed of soft minerals and mostly crystal silicate groups. Medical applications of montmorillonite include the treatment of irritable bowel syndrome, prevention of constipation and aflatoxin. It also inhibits the intestinal adsorption of cholesterol. These kinds of clay minerals (a group of phyllosilicates) can also be utilized as drug carriers and controllers for drug liberation. It also inhibits the intestinal adsorption of cholesterol. Altogether, it can be used as an adsorbent for heavy metals, poisons and hazardous chemical substances such as removal of mercaptan sulfur from kerosene-oil and $\mathrm{Cu}$ (II), $\mathrm{Zn}(\mathrm{II}), \mathrm{Cd}(\mathrm{II})$ and $\mathrm{Cr}$ (III) from aqueous solutions by sorption on the montmorillonite clay from was investigated ${ }^{13-19}$. Activated clay has been successfully applied for the removal of dyes in the industrial textile wastewater. Activated clay has proved its effectiveness as $98 \%$ of the dyes and the COD is reduced from $10800 \mathrm{ppm}$ to $32 \mathrm{ppm}$ with a neutral $\mathrm{pH}$ and an excellent decantability ${ }^{20}$.

The properties of composite sheets composed of acid lactic polymer and montmorillonite modified with quaternary ammonium salt improved the strength, membrane, water 
vapour penetrability and antimicrobial properties of natural montmorillonite-composite ${ }^{21}$. The properties of natural montmorillonite and silver-composites indicate that the antimicrobial properties have increased ${ }^{22}$. Seckin and his colleagues have investigated the antimicrobial properties of montmorillonitepoly vinyl pyridinium matrix composites and reported a decrease in the number of bacterium cells in water ${ }^{23}$. In other studies, substitutable ions of montmorillonite were replaced by silver or copper and showed better antimicrobial properties in comparison to these metals ${ }^{24,25}$.

The antimicrobial properties of four clay minerals intercalated by quaternary phosphonium salt (tetradecyl tributyl phosphonium bromide, TDTB) were studied. According to the results antimicrobial activity of organ-clay minerals depended on three factors i.e., they are the releasing amount of tetradecyl tributyl phosphonium bromide, surface charge and particle size of organ-clay minerals. It was shown that antimicrobial activity was the synergic effect of the three factors. Montmorillonite-TDTB exhibited the highest antimicrobial activity because of releasing amount of organic antimicrobials ${ }^{26}$. The nano-structured as antibacterial agents include $\mathrm{TiO}_{2}$ nano-particles, metallic and non-metallic $\mathrm{TiO}_{2}$ (nano) composites, titania nanotubes, silver nano-particles, silver-based nano-structured materials, gold nano-particles, zinc oxide nano-particles and nano-rods, copper nanoparticles, stannous chloride, carbon nanotubes, carbon black, montmorillonite and its modified forms, gallium, liposomes loaded nano-particles, metallic and inorganic dendrimers (nano)composite, nano-capsules and cyclodextrins containing nano-particles ${ }^{27}$.

Despite the vast use of silicate clay in textile industry, the antimicrobial properties of montmorillonite clay and its application on cotton is investigated. We have also tried to investigate modification of montmorillonite clay with cation in achieving good antimicrobial properties on cotton material.

\section{EXPERIMENTAL}

Materials used in this research including montmorillonite clay (MMT) and modified montmorillonite clay with quaternary ammonium salt (A-MMT) is prepared from SCP, U.S.A. The incubation environment, namely tryptic soy agar, containing agar, protein, casein and soy protein, supplied from Merck, Germany. A cotton fabric with weight of $322 \mathrm{~g} / \mathrm{m}^{2}$ used to measure the antimicrobial properties.

Clay dispersion samples: $1 \mathrm{~g}$ of montmorillonite clay powder and1 $\mathrm{g}$ of modified montmorillonite clay powder individually soaked in distilled water for $24 \mathrm{~h}$. dispersion of MMT and A-MMT is considered for evaluation of antibacterial activity based on assay of minimum inhibitory concentrations of antibacterial agent.

Application on cotton fabric: The cotton fabrics treated individually with 30, 20, 10 and $5 \%$ (o.w.f) of MMT and AMMT for $1 \mathrm{~h}$, at $60^{\circ} \mathrm{C}$ and $\mathrm{pH}=7$. The samples are considered from all treated and untreated fabrics for evaluation of antibacterial activity and they are coded 30 MMT, 20 MMT, 10 MMT, 5 MMT, 30 A-MMT, 20 A-MMT, 10 A-MMT and 5 AMMT respectively.

Testing: A specific amount of MMT and A-MMT sample was chosen, $0.5 \times 0.5 \mathrm{~cm}^{2}$ pieces were cut out from each cotton treated with MMT and A-MMT, each was fixed on a stand and then sputter coated with gold, using Sputter couter machine, model SCD00S, from BAL-TECH company, Switzerland. Micrographs of each samples were taken using scanning electron microscope (SEM), model XL30, from Netherland's Philips. Fourier transformed infrared spectrometer (FTIR) spectra 4000-400 $\mathrm{cm}^{-1}$ were collected on a Nicolet 6700 spectrometer.

The antimicrobial activity of montmorillonite (MMT) and modified montmorillonite (A-MMT) were evaluated by determining the minimum inhibitory concentrations (MIC) by two-fold serial dilutions of MMT and A-MMT. Each $1 \mathrm{~mL}$ of culture medium containing various concentrations of test sample was inoculated with $0.1 \mathrm{~mL}$ of $107 \mathrm{cfu} / \mathrm{mL}$ bacterial suspension (determined by "standard plate count"), cultured for $24 \mathrm{~h}$ at $37^{\circ} \mathrm{C}$ under shaking and then the growth of bacteria was observed. MIC values were determined as the lowest concentration of the tested sample where the absence of growth was recorded ${ }^{26}$.

Quantitative experiments of antibacterial activity for MMT and A-MMT also cotton treated with MMT and A-MMT are conducted according to AATCC 100-2004 standard test method, using gram-positive bacteria; Staphylococcus aureus, gram-negative bacteria; Escherichia coli. In this method, samples placed next to a dispersion of bacterium according to McFarland's standard. At the end, the number of colonies determined using eqn. 1.

$$
\mathrm{C}=\frac{\mathrm{M}_{1}-\mathrm{M}_{2}}{\mathrm{M}_{1}} \times 100
$$

where, $\mathrm{C}$ : Per cent of decreasing, $\mathrm{M}_{1}$ : Number of colonies in control microbial dispersion and $\mathrm{M}_{2}$ : Number of colonies existing in the dispersion after being co-located adjacent to treated samples.

\section{RESULTS AND DISCUSSION}

Microscopic images and elemental analysis (EDAX): The SEM images of A-MMT and MMT showed in Fig. 1. These images indicated the shape of modified montmorillonite and montmorillonite are clay layers and based on EDAX curve in Fig. 4, montmorillonite and modified montmorillonite include silicate layers clay.

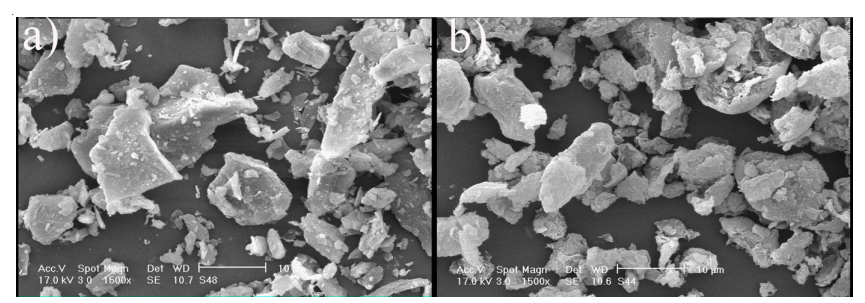

Fig. 1. SEM pictures of A-MMT (a) and MMT (b)

The SEM images of E. coli bacteria and departed E. coli bacteria with modified montmorillonite layers showed in Fig. 2. The destructive effect of A-MMT dispersion on the morphology of the bacterial species (E. coli) was evaluated by SEM after $24 \mathrm{~h}$ of bacteria incubation with A-MMT dispersion. SEM images demonstrated that cell structure of all bacteria had changed and become agglomerated after being 
in contact with the A-MMT dispersion. These images are shown completely that layers montmorillonite clay attach to cellular surface of $E$. coli bacteria, decrease its permeability and dead of bacteria ${ }^{26}$.
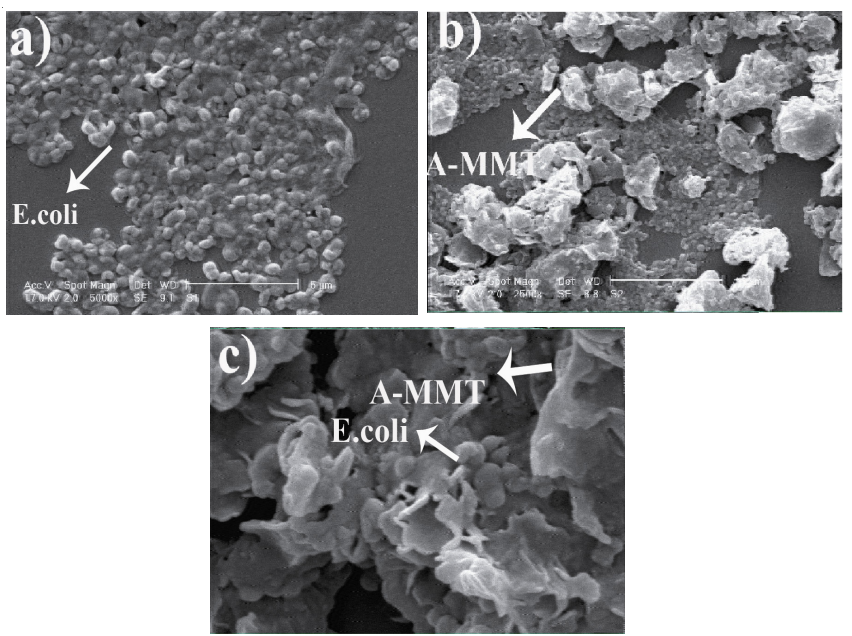

Fig. 2. SEM pictures of (a) E. coli bacteria (b) A-MMT (c) A-AMT treated E. coli

The SEM images of untreated cotton fiber, treated cotton fiber with MMT and A-MMT showed in Fig. 3. By comparing the fiber surfaces of untreated sample with treated sample, it could conclude that montmorillonite layers deposited on fiber surfaces. This evidenced the penetration of MMT and A-MMT into the inner surfaces of fibers. Therefore, samples treated showed antibacterial properties through antibacterial experiments and the existent clay layers in fibers destroyed the bacteria completely. The elemental analysis of untreated and the sample treated with A-MMT showed in Tables $1 \mathrm{a}$ and 1b, it merely indicates gold (which used as a covering before capturing images), whereas the sample treated with A-MMT included calcium, sodium, silica and magnesium elements. Comparing the chemical structure of montmorillonite clay, indicated the existing elements on the surfaces of samples and related to montmorillonite clay and their deposition on sample surfaces which, in turn, resulted in antibacterial properties of the fibers.
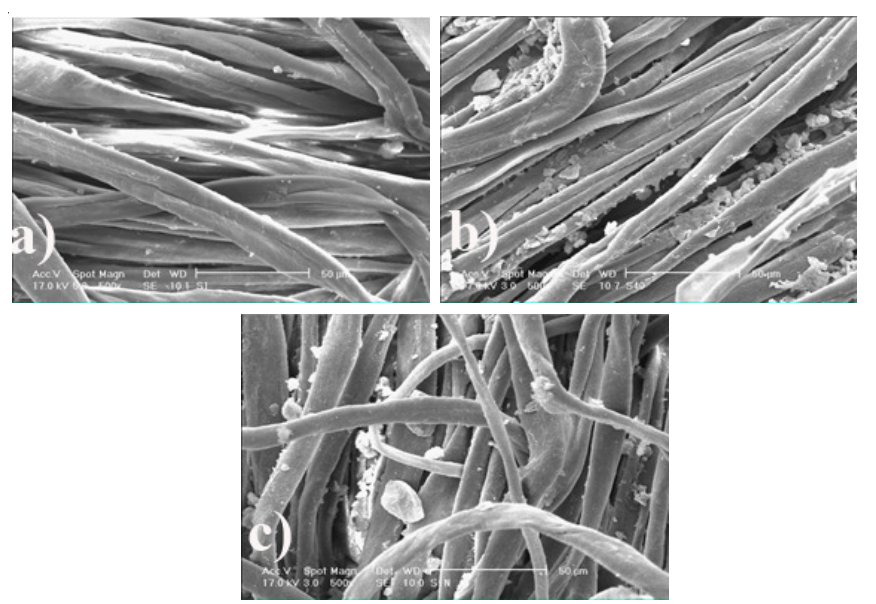

Fig. 3. SEM pictures of the cotton fiber; Untreated cotton fibers (a), cotton fibers treated with A-MMT (b), cotton fibers treated with MMT (c)

\begin{tabular}{ccc} 
& TABLE-1a \\
\hline Element & Wt $\%$ & At $\%$ \\
\hline $\mathrm{Au}$ & 91.71 & 61.04 \\
\hline Total & 100 & 100 \\
\hline
\end{tabular}

\begin{tabular}{ccc}
\multicolumn{3}{c}{ TABLE-1b } \\
\hline Element & Wt \% & At \% \\
\hline $\mathrm{Mg}$ & 0.11 & 0.69 \\
$\mathrm{Al}$ & 0.76 & 4.24 \\
$\mathrm{Si}$ & 1.93 & 10.32 \\
$\mathrm{Na}$ & 0.43 & 1.65 \\
$\mathrm{Ca}$ & 0.56 & 2.08 \\
$\mathrm{Au}$ & 93.86 & 71.48 \\
\hline Total & 100 & 100 \\
\hline
\end{tabular}

XRD and FT-IR analysis: The XRD patterns of untreated and treated cotton with A-MMT are presented in Fig. 4. The untreated cotton enjoyed a definite pattern created peaks at the specific angles. However, those treated cotton with $30 \%$ A-MMT indicated different peaks at $65-80^{\circ}$ confirming the presence of montmorillonite layers on their surface. Therefore, the X-ray diffraction patterns indicated loading of the montmorillonite clay with open layers on the fiber surfaces that also penetrated into fibers and distributed more appropriately as presented by SEM pictures.

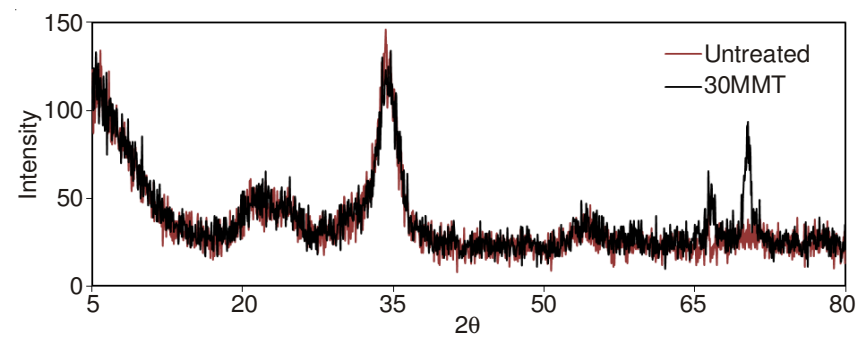

Fig. 4. XRD curves of untreated cotton and cotton fiber treated with AMMT

The FT-IR curves of the montmorillonite and modified montmorillonite are illustrated in Fig. 5. It can be seen that the chemical structure of the montmorillonite clay (MMT) has been changed after modification by quaternary ammonium salt. This can be due to creating new chemical groups based on ammonium group $\left(\mathrm{NH}_{3}{ }^{+}\right)$on montmorillonite clay thus, bands at 2926, 2855 and $1100 \mathrm{~cm}^{-1}$ of A-MMT were attributed to the presence of symmetrical and asymmetrical modes of the ammonium group $\left(\mathrm{CH}_{2}\right)$ bending vibration of the quaternary salt part of A-MMT ${ }^{26}$.

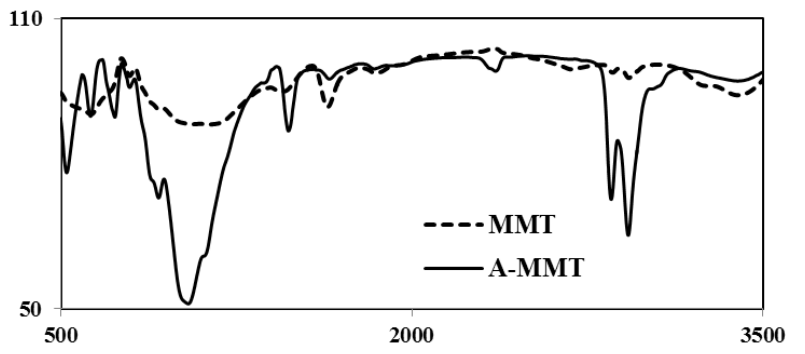

Fig. 5. FT-IR curves of A-MMT and MMT

Antibacterial activity of montmorillonite clay: The MIC of modified montmorillonite clay (A-MMT) and montmori- 
llonite clay (MMT) on E. coli and S. aureus were shown in Table-2. A-MMT displayed the highest antimicrobial activity than MMT, with $4096 \mu \mathrm{g} \mathrm{mL}^{-1}$ and $5051 \mu \mathrm{g} \mathrm{mL} \mathrm{m}^{-1}$ of MIC on E. coli and $S$. aureus respectively.

TABLE-2

MIC OF MMT AND A-MMT ON E. coli AND S. aureus

\begin{tabular}{ccc}
\hline \multirow{2}{*}{ Samples } & \multicolumn{2}{c}{${\text { MIC/ } \mu \mathrm{g} \mathrm{Ml}^{-1}}^{2}$} \\
\cline { 2 - 3 } & E. coli & S. aureus \\
\hline MMT & $>16384$ & $>16384$ \\
A-MMT & 4096 & 5051 \\
\hline
\end{tabular}

Antibacterial properties of montmorillonite clay (MMT), modified montmorillonite clay (A-MMT) were investigated through a quantative method and decrease in the number of bacteria colonies calculated before and after being placed adjacent to samples and the results showed in Table-3. The AMMT sample led to a decrease in the number of $S$. aureus and $E$. coli bacteria colonies which evidences the antibacterial effect of modified montmorillonite. Based on the opening of layers of montmorillonite in disperse sample, the layers of AMMT could attach to the cellular surface of bacteria, decrease its permeability and killed the bacteria ${ }^{26,27}$. The modification of montmorillonite with quaternary ammonium salt has enhanced the antibacterial effect of MMT. This is due to the attachment of montmorillonite layers to the cell membrane of microbe; the cation reactions of A-MMT with the anions in the cell wall will result in bacteria death ${ }^{25-27}$. Dispersed MMT decreased the number of $S$. aureus and E. coli bacteria colonies, but the decreasing in the number of colonies by montmorillonite is less than that of the modified montmorillonite (A-MMT). Investigations indicated that A-MMT have less effect on gramnegative bacteria in comparison of gram-positive bacterium (S. aureus).

Antibacterial properties of treated cotton: The antibacterial properties cotton treated with different concentration of montmorillonite and modified montmorillonite showed in Table-3. The untraded cotton resulted in an uncountable increase in the number of bacteria colonies and thereby providing an appropriate condition for bacteria growth and resulted in an increase in bacteria colonies. A decrease of bacteria colony numbers indicated with the treated cotton with montmorillonite. Treated cotton samples with A-MMT have better antibacterial than cotton samples treated with MMT because of the cation reactions of A-MMT with the anions in the cell wall will result in higher bacteria death. With increasing of montmorillonite concentration, antibacterial activity of treated cotton increased. Treated cotton with 10, 20 and $30 \%$ of modified montmorillonite has good antibacterial activity and the changes of concentration from 10 to $30 \%$ have no effect on antibacterial properties of treated cotton with A-MMT because of cationic modifier (quaternary ammonium salt) that it increased of antibacterial activity of modified montmorillonite. Thus, cotton treated with 5 or $10 \%$ of A-MMT and cotton treated with 20 or $30 \%$ of MMT has good antibacterial, although antibacterial properties of cotton treated with modified montmorillonite better than cotton treated with montmorillonite. Also, the result indicated that increasing of montmorillonite concentration in treated cotton with MMT is caused increasing of antibacterial activity of treated cotton and the changes of montmorillonite concentration were effective on antibacterial properties of treated cotton.

\begin{tabular}{lcc}
\hline \multicolumn{3}{c}{ TABLE-3 } \\
\multicolumn{3}{c}{ REDUCTION PERCENT OF DIFFERENT BACTERIA } \\
& AGAINST VARIOUS COMPOUNDS \\
\hline Samples & Reduction (\%); S. aureus & Reduction (\%); E. coli \\
\hline A-MMT & 99.1 & 99.3 \\
MMT & 83.0 & 80.5 \\
Untreated & 0 & 0 \\
5 A-MMT & 95.3 & 96.6 \\
10 A-MMT & 99.3 & 100.0 \\
20 A-MMT & 99.4 & 100.0 \\
30 A-MMT & 99.4 & 100.0 \\
5 MMT & 80.1 & 86.6 \\
10 MMT & 81.5 & 89.1 \\
20 MMT & 85.4 & 89.5 \\
30 MMT & 89.7 & 90.6 \\
\hline
\end{tabular}

\section{Conclusion}

This paper studied the antibacterial activity of montmorillonite clay (MMT) and modified montmorillonite (A-MMT) compounds and investigates and reports their effect on cotton fiber. MMT modified with ammonium quaternary salt, showed better antibacterial properties compared to MMT. Furthermore, cotton fiber treated with both of montmorillonite had antibacterial properties. With increasing of montmorillonite concentration in cotton treated MMT and A-MMT, antibacterial properties are increased, but cotton treated with 10\% A-MMT had best antibacterial activity than treated cotton with MMT.

\section{REFERENCES}

1. S.Q. Jiang, E. Newton, C.W.M. Yuen and C.W. Kan, J. Appl. Polym. Sci., 96, 919 (2005).

2. K. Saengkiettiyut, P. Rattanawaleedirojn and S. Sangsuk, Nanotechnology, 7, 33 (2008).

3. A.P. Mishra and M. Khare, Asian J. Chem., 10, 633 (1998).

4. R.K. Patel, K.M. Purohit and R.N. Patel, Asian J. Chem., 11, 490 (1999).

5. A.S. Khoulya, E. Kenawya, A.A. Safaan, Y. Takahashi, Y.A. Hafiz and K. Sonomoto, Carbohyd. Polym., 83, 346 (2011).

6. X. Fu, Y. Shen, X. Jiang, D. Huang and Y. Yan, Carbohyd. Polym., 85, 221 (2011)

7. R. Saraswathi, P.N. Krishnan and C. Dilip, Asian Pacific J. Trop. Med., 3, 128 (2010).

8. Y.H. Kim and G. Sun, Text. Res. J., 71, 318 (2001).

9. M. Montazer and F. Rangchi, Tekstil Ve Konfektiyon, 2, 128 (2009).

10. Y.A. Son and G. Sun, J. Appl. Polym. Sci., 90, 2194 (2003).

11. F. Zhang, D. Zhang, Y. Chen and H. Lin, Cellulose, 16, 281 (2009).

12. P. Desai, A.C. Champaner and K.R. Desai, Asian J. Chem., 12, 1320 (2000).

13. K.G. Bhattacharyy and S.S. Gupta, J. Colloid Interf. Sci., 140, 114 (2008).

14. M.I. Carretero and M. Pozo, Appl. Clay Sci., 47, 171 (2010).

15. J.W. Early, B.B. Osthaus and I.H. Milne, Am. Mineral., 38, 707 (1953).

16. D. Yang, P. Yuan and W. Shen, J. Colloid Interf. Sci., 297, 235 (2006).

17. F. Gode, Asian J. Chem., 19, 2211 (2007).

18. M. Jaiswala and A. Maheshwari, Asian J. Chem., 11, 858 (1999)

19. V.S. Palria, S.K. Parihar and S. Tak, Asian J. Chem., 14, 911 (2002).

20. H. Bouabdesselam, S. Meddah, Y. Bouzidi and D. Bourg, Asian J. Chem., 17, 2291(2005).

21. J.W. Rhim, S. Hong and C. Ha, Food Sci. Technol., 42, 612 (2009).

22. H.L. Su, C.C. Chou, D.J. Hung, S.H. Lin, I.C. Pao, J.H. Lin, F.L. Huang,, R.X. Dong and J.J. Lin, Biomaterials, 30, 5979 (2009).

23. T. Seckin, Y. Onal, O. Yesilad and A. Gultek, J. Mater. Sci., 32, 5993 (1997).

24. C.H. Hu, Z.R. Xu and M.S. Xia, Veterinary Microbiol., 109, 83 (2005).

25. S.M. Magana, P. Quintana, D.H. Aguilar, J.A. Toledo, C. AngelesChavez, M.A. Cortes, L. Leon, Y. Freile-Pelegrin, T. Lopez and R.M. Torres Sanchez, J. Mol. Catal. A, 281, 192 (2008).

26. T. Wu, A.-G. Xie, S. Tan and X. Cai, Colloids Surf. B, 86, 232 (2011).

27. R. Dastjerdi and M. Montazer, Colloids Surf. B, 79, 5 (2010). 